\title{
Poetic Deviances, Lessgo Deconstruct the Master's Tools: Creatively Critical Talanoa Mālie and Critical Autoethnographic Defiance
}

\author{
David Taufui Mikato Fa'avae, Edmond Fehoko, Sione Siu'ulua and Finausina Tovo
}

\begin{abstract}
Indigenous Pacific knowledges embody creative modes of expression and sensibilities as meaning-making. Academia, as a Western-oriented institution, however, privileges intellectualisations that favour abstract critical thinking through more objective lenses. As Moana-Pacific-Pasifika researchers, being creatively critical in higher education begins from our Indigenous concepts and creative practices such as poetry. Talanoa mālie provides a worldview of being-knowing-seeing-doing that we inhabit as Tongans within higher education beyond the boundaries of our ancestral fonua or whenua. Our critical autoethnographic reflections as early career academics are woven through and positioned within our wider talatalanoa, which ultimately seeks to defy, disrupt, and deconstruct dominant Western academic tools and practices within the university context in Aotearoa-New Zealand.
\end{abstract}

\section{Introduction}

Deconstruction is a tool of disruption in the master's house, that is, of Western-oriented academia. The Algerian-born French philosopher, the late Jacques Derrida, utilised deconstruction to analyse text, language, and symbols. He argued that "deconstruction is neither an analysis nor a critique ... because the dismantling of a structure is not a regression toward a simple element, toward an indissoluble origin." Deconstructing the master's tools is not primarily focused on reaching a desired outcome. The processes of deconstruction and analysis in themselves warrant further deconstruction and analysis, highlighting deconstruction's iterative nature. Storying our reflections of the current conditions, navigating academia and how this generation of early career Indigenous Pacific scholars address, defy, disrupt, and inspire ways to counter the normalised ideals and practices inherent in the architectures of the university in Aotearoa-New Zealand, is in itself worthwhile and ongoing.

We prioritise reflexivity, writing, and expression largely from a Tongan worldview. Our main claim is that the skill and knowledge of abstract critical thinking as a fundamental ideal of intellectualising does not always capture what is profoundly mālie ${ }^{2}$ and māfana ${ }^{3}$ to Tongan researchers and their communities. ${ }^{4}$ Talatalanoa is the iterative and ongoing unfolding of reflections and meaningful engagement, guided by talanoa mālie and māfana. Our becoming creatively critical require us to viscerally engage and work with Indigenous Pacific language, knowledges, and cultural practices in ways that evoke in-depth or lōloto work, and are in tune with the rhythms within the loto (soul, heart).

The paper demonstrates how we can advance the field of academic intellectualising by centring on lea fakaTonga (Tongan language) and Tongan ideas, and articulating the ways early career academics embrace and encounter such critical moments through the creative ways we embody and manifest becoming creatively critical. The main aim of our paper is to articulate what it means to do creatively critical work within the academy as Pacific/Pasifika early career researchers. To capture creatively critical work, we draw from our reflexive experiences within universities as data sources. To unfold our sense making of creatively critical practice, we utilise poetry and poems to portray our thoughts and meaning-making. Finally, we conclude 
by asking, where to next? Ongoing talatalanoa, and a summary of some critical insights to help us continue our creatively critical meaning-making.

\section{Poetry as a Creatively Critical Source and Tool}

The late Audre Lorde's daring theorisations and defiant poetic fluency has inspired many poets and emerging scholars around the world. The self-proclaimed Black lesbian, mother, warrior, and poet infuses a criticality that saturates creative defiance through her powerful and vigilant wordsmithing, carefully chosen and penned on paper, giving her words life beyond the pages, leaving a felt resonance for many who read her work. ${ }^{5}$ For us, the authors of this paper, this is what poetry beyond tu'atonga illuminates. ${ }^{6}$ In Lorde's text, The Master's Tools Will Never Dismantle The Master's House, she articulates poetry thus:

The quality of light by which we scrutinize our lives has direct bearing upon the product which we live, and upon the changes which we hope to bring about through those lives. It is within this light that we form those ideas by which we pursue our magic and make it realized. This is poetry as illumination, for it is through poetry that we give name to those ideas which are - until the poem-nameless and formless, about to be birthed, but already felt. The distillation of experience from which true poetry springs births thought as dream births concept, as feeling births idea, as knowledge births (precedes) understanding. ${ }^{7}$

To dismantle the master's house, as alluded to by Lorde, poetry is a tool for deconstruction. Poetry is embodied critical deviance and defiance. It is the art of critical sense making. Lorde claims poetry is a vital necessity of women's existence through the "way we help give name to the nameless so it can be thought." ${ }^{8}$ Aotearoa-New Zealand-born and raised scholars of Samoan-Papālagi and Tongan-Papālangi ancestries, Jacoba Matapo and Jean Allen employ poetry as an expressive and embodied act. ${ }^{9}$ Poetry was used to story their personal journeys, traversing identity, experience, education, and belonging in Aotearoa-New Zealand. Robert Rinehart articulates poetry as "a sensibility to things poetic, to poetic practice, to engage in the world in poetic ways, to thinking poetically ... [it] allows educational researchers to manifest a distinction between what Dewey termed the subject and [the] substance of poetics." ${ }^{10} \mathrm{He}$ further defines poetic sensibility as a "way of viewing and experiencing the world that yearns for novelty, that hungers for metaphors, that links disparate elements together in new ways." 11

Throughout the paper, we unpack our creatively critical reflections and thinking using poetry as a mode of expression. The poems are constructed and woven together using Tongan ideas together with lea fakaPilitania (English language). Poetic sensibility connects the mind, heart, and soul. It arouses sense making beyond the seen, into the unseen. Poetic sensibility honours embodied meaning-making. As modes of expression, poetry arouses our senses and triggers our abstract bodily spiritual rhythms, which are often brought to light expressively through talatalanoa performativity. Talanoa mālie and talatalanoa are sense making expressed, performed, and mediated. The ongoing storying and inquiring involved in the tala-tala-noa ${ }^{12}$ echoes mālie rhythms and energy centred on our vā relations, aspirations, and inspiration. 


\title{
Why Weave Practices? Talatalanoa and Critical Autoethnographic Articulations
}

\author{
To tala or story \\ a tale of knowing \\ is to tell an unknown story
}

To sio or see

a story of being

is to ongo'i our becoming

To ngāue' aki or do

a story of our seeing

is to care for our knowing

Caring for our becoming (Sunday, 24 October 2021, 10pm)

Our becoming in the world is creative practice. Capturing creatively critical meaning-making that integrates Tongan and Western concepts, through the dual use of talatalanoa and critical autoethnography, is to highlight what it means to engage in research practices in tu'atonga. Although talatalanoa and critical autoethnography privilege reflexive thinking and storying from the margins, their knowledge traditions, and their ways of languaging and sense making are different. For us, our starting point is often a Tongan sociocultural position. The ideas, conversations, aspirations, and concerns in this paper are ongoing and its purpose is to engage readers: to get them to care about our becoming creatively critical within academia. Our collaborative reflections provide diasporic understandings of what it means to advocate and promote thinking, writing, and expressing through talanoa mālie and talatalanoa.

Talatalanoa is a derivative of talanoa, mainly used in collective contexts, defined as a dialogic practice. ${ }^{13}$ Dialogic is a style of discourse linked to dialogue as a practice. Within Tongan contexts, talatalanoa is ongoing and iterative in form and style. When deconstructed, tala (to story, tell, talk, dialogue) is intricately linked to noa (something unknown). When tala-tala-noa are coupled together, the ways in which meaning-making takes place are diverse and nuanced because the practice of talatalanoa is reliant on the people involved, the context, the matter of concern, and the spirit that governs engagement. What talatalanoa looks and feels like for one group of people may not be the same as for another. The spirit of vā, aided by māfana and mālie, can be manifested in talatalanoa, and unless they are invoked by people and entities during the dialogue or conversation, such spiritual entities will not eventuate and generate emotive sensibilities linked to loto fiefoaki (generosity), loto 'ofa (love and care), and loto toka' $i$ (deep respect). Though embarking on postgraduate studies in 2012, David never fully realised talanoa's potential as a research approach until he started his doctoral studies in 2014 at Te Puna Wānanga, the School of Māori and Indigenous Education at the University of Auckland.

Working with critical autoethnography led Fetaui Iosefo, an Aotearoa-New Zealand-born and raised Samoan, to capitalise on Samoan concepts that provided a form of resistance work against dominant Western and historically privileged research practices. She claims that "combining and weaving postcolonial and Samoan theories together to address the dominant culture is congruent with the process of constructing and deconstructing my identity within the spaces of higher education." 14 The "critical in critical autoethnography reminds us that theory is not a static or autonomous set of ideas, objects, or practices. Instead, theorising is an ongoing 
process that links the concrete and abstract, thinking and acting, aesthetics, and criticism in what performance studies scholar Della Pollock describes as living bodies of thought." 15 Research literature strengthens critical practice and analysis within critical autoethnography.

For us, learning about how other Tongan scholars from other disciplines utilise Tongan conceptual tools alongside Western theories provided in-depth speculations of creatively critical possibilities in practice. Both talatalanoa and critical autoethnography empower marginalised scholars and provide them with the critical depth work that resists colonial and dominant practices. For Moana-Pacific-Pasifika scholars, the dual use of talatalanoa and critical autoethnography strengthens research resistance work. However, it is necessary to articulate the contexts as well as challenges experienced and negotiated in the dual implementation of Indigenous Pacific approaches together with Western approaches to research. Ignoring such complexities and tensions can lead to "ungrounded philosophising and lazy theorising." 16 In this paper, as part of our decolonial research resistance, we bring into practice talatalanoa and critical autoethnography to enable the deconstruction and reconstruction of the non-static or autonomous state of theorising, thinking, and acting, instead showing them as ongoing, iterative, and generative in nature.

The dual utilisation of talatalanoa and critical autoethnography is creatively critical practice. Their dual integration is an appreciation of the subtle and nuanced realities of Tongan communities who are drawing from their Tongan cultural capital (valued knowledges and practices) within large urban and cosmopolitan contexts in Aotearoa-New Zealand and the United States, indicative of what it means to grow up and live as a Tongan born and raised in tu'atonga. Enabling the dual practice of talatalanoa and critical autoethnography highlights for our next generation-who may also be of mixed Moana-Pacific-Pasifika ethnicities and race-how to appreciate and embrace the complexities and be open about exploring their challenges as well as reimagining their possibilities within their lived contexts and time.

Creatively critical is learning to appreciate not only the challenges associated with integrating talatalanoa and critical autoethnography, but the forms and modes of appropriately expressing, presenting, and representing our critical reflections. Similarly, "creatively critical" embraces digging deep into grounding whakapapa/fakahohoko (genealogical) work, navigating as well as negotiating one's scholarly thinking, practice, and trajectory from that particular place and space. ${ }^{17}$ Our willingness to articulate clearly the whakapapa/fakahohoko work and how we intend to specifically do this kind of work in our research context will contribute to what Tui Atua Tupua Tamasese Ta'isi 'Efi (Tui Atua) refers to as a necessary decluttering of Pacific knowledge making within Western research. ${ }^{18}$ We declutter in this paper by acknowledging the ancestral roots of Tongan ideas and articulate the ways we purposefully utilise them in our creatively critical writing.

\section{Creatively Critical Becoming: Moana-Pacific-Pasifika}

The terms "Moana," "Pacific," and "Pasifika" are descriptors used interchangeably by educators and researchers to position themselves, to relate themselves to places and spaces. Each descriptor is evident within education and academic contexts, employed to ground and articulate peoples' and community's relational positioning within the whenua or fonua (land), including philosophical and theoretical spaces. ${ }^{19}$ Moana-Pacific-Pasifika have historical whakapapa and contextual meanings that were relevant at the time of their construction to, by, and for the people of that era and place. They are social and geographical descriptors that carry in-depth meaning and decolonial resistance. For instance, the term Moana refers to Oceania and was used in the 1980s by scholars like Epeli Hau'ofa and Maualaivao Albert Wendt to 
counter the use of Pacific because of its colonial undertone. ${ }^{20}$ Tongan poet and scholar Konai Helu Thaman prefers "my Pacific is Oceania" because it includes the colonial histories that have shaped our current education and societal contexts. ${ }^{21}$ The use of Pasifika as a descriptor in Aotearoa-New Zealand is "more about the power to name." 22 Pasifika "originated from us, [and that] is of no small consequence because being able to define ourselves is an issue of control." 23

Linitā Manu'atu is a defier of dominant Western academic traditions, pushing boundaries in order to gauge and engage with thinking and writing that encapsulates loloto criticality from Tongan perspectives. ${ }^{24}$ She was the first to conceptualise and implement the concept of mālie in research contexts as a way of "decolonizing the thinking of Tongan people, to draw upon their concepts, values, and beliefs in their own Tongan language for ideas to deepen their thinking about their education, pedagogies, and philosophies." 25

Digging deep into Tongan knowledges and philosophies through lea fakaTonga requires meaning-making processes that connect with the loto. This kind of heart-work criticality is often undervalued in Eurocentric university institutions. Certainly, within disciplinary traditions like education and the social sciences, critical understanding from and through the loto is deemed as lacking critical objectivity, a stance privileged as critical thinking within western academia. ${ }^{26}$ The search for mālie including māfana and its possibilities is a defiant yet generative practice that can empower Pacific/Pasifika scholars within Western academia. ${ }^{27}$ The faikava, for instance, is a valued sociocultural practice of Moana-Pacific-Pasifika people in the diaspora. ${ }^{28}$ Even non-Pacific people are engaging in social and research spaces and conversations with those of Moana-Pacific-Pasifika heritages. ${ }^{29}$

Grounded in the fonua

a plant and beverage of the Pacific

fonua consumed

enabling harmonious talanoa-vā and mālie

Grounded in the culture

(re)searching cultural practices

lost in translation

across social spaces

Tama Tonga-Tonga!

Ma'u leva ho'o kava

accept your kava!

Ho'o koloa ke fakamonū - to laud our culture!

Kava-Navigating fonua in New Fonua (Thursday, 21 October 2021, 1pm)

\section{Creatively Critical Becoming Tongan in Tu'atonga: Evolving Languages, Cultures, Identities}

We cannot help but consider the state of our becoming Tongan in tu'atonga, particularly in an era filled with precariousness and uncertainties. In August 2021, the whole of Aotearoa-New Zealand was in level 4 lockdown, a response to the delta variant of the COVID-19 virus. So what does this mean for Tongan people and their knowledges, languages, identities outside of the ancestral homeland? At university, what is the place of "feeling" within being, knowing, seeing, and doing? Although the questions raised are not answered directly in this paper, they 
highlight the need to reimagine our evolving Moana-Pacific-Pasifika languages, cultures, and identities, as they are realised within education contexts globally.

Pasifika and non-Pasifika scholars argue fluency in a Pasifika language in Aotearoa-New Zealand can strengthen an individual's sense of connection with a culture and identity. ${ }^{30}$ Developing teachers' capacity to appreciate the pluralities of Pasifika ethnicities, races, and cultural identities continues to be a struggle. Of concern are the limited open conversations about the evolving nature of the Tongan language, concepts, and cultural practices in tu'atonga and their implications for young peoples' sense of belonging and becoming as Aotearoa-New Zealand-born and raised. During a recent talanoa online, Manu'atu claims in-depth theorising requires one to be grounded in a particular language, whether it is in Tongan or English. She believes lōloto undertakings or critical depth work within higher education is reliant on one's sense of grounding in a particular knowledge system. The Tongan linguist Melenaite Taumoefolau describes tu'atonga theorising as being linked to the evolving nature of lea fakaTonga. ${ }^{31}$ Tongan anthropologist Tēvita Ka'ili states:

Ka mole etau lea, mole moe fonua. Pea koe taimi 'oku iai ha liliu hoko kihe fonua, kuo pau ke hoko pe moe liliu koia kihe etau lea. .. . Kapau tetau hokohoko atu, kuo pau pē ke liliu etau lea. Kapau koe tufunga lea, pau pe ke 'uhingamālie. Kapau tetau ohi lea, 'oku mahu'inga ke ongomālie. ${ }^{32}$

If we lose our language [lea fakaTonga], we lose our [connection] to land. And when there are changes (new developments) to Tonga (land), they are bound to impact our language... if we continue this way our language has to change. With language structure, it has to be meaningful. If we 're adopting language, it's important the words sound and feel meaningful/appropriate.

Ka'ili uses the words 'uhingamālie (meaningful) and ongomālie (sounds and feels meaningful/appropriate) when thinking about the evolution of lea fakaTonga, whether lototonga (within Tonga) or tu'atonga (outside of Tonga). ${ }^{33}$

Within Aotearoa-New Zealand higher education, there is a growing number of doctoral candidates and graduates of Tongan ancestry. The ongoing deficit focus amongst Tongan communities, describing the Aotearoa-New Zealand-born and raised generation as lacking Tongan language fluency and a strong sense of cultural identity, continues to fester in schooling as well as university settings. Connecting and building on the identity constructions and negotiations of Tongan people in the diaspora of Aotearoa-New Zealand, Australia, and the United States is much needed. Providing such generative spaces to grow our next generation of Tongan as well as Moana-Pacific-Pasifika researchers relies on intergenerational collaboration with our more experienced scholars. It does, however, also require vulnerable yet open conversations based on loto fiefoaki (generosity, care) and loto toka' $i$ (deep respect), as well as the overarching vision to grow and nurture our to'utangata Tonga.

Alice Te Punga Somerville urges researchers to articulate the specific differences between Māori and Pacific peoples and the ways in which they think and practice their creative criticality as Indigenous scholars within western academia. In her book, Once Were Pacific, she unpacks Māori ancestral connections to Oceania. ${ }^{34}$ Her text provides a sense of criticality within indigeneity scholarship that brings attention to our own cultural politics and the obvious yet subtle ways in which particular knowledges, meaning-making, and practices privilege certain Pacific/Pasifika ethnic groups over others. Our next generation of Pacific/Pasifika early career scholars and researchers located in Aotearoa-New Zealand have embraced critical 
defiance, in various ways, from diverse vantage points. ${ }^{35}$ Within higher education, LeenenYoung et al., Thomsen, Lopesi and Tecun, Fehoko, Baice et al., and Havea et al. have all contributed critical talanoa and forms of writing that we think, as described by McDowall and Ramos, provide a form of epistemic disobedience. ${ }^{36}$

Engaging in this special issue with other Moana-Pacific-Pasifika early career scholars and researchers encourages our defiant criticality, saturated through lea fakaTonga and lea fakaPilitania. Our paper is an attempt to make sense of as well as disrupt the normative Eurocentric and dominant practices linked to critical scholarly thinking and writing.

\section{Creatively Critical Languaging: Urban Colloquial Slang}

The "lessgo" (or leshgo) contraction of "let's go," as articulated by Lana Lopesi, an early career scholar of Samoan ancestry, is regularly used as a brown urban colloquial saying to hype and energise people, especially when things seem challenging and difficult. ${ }^{37}$ Lopesi traces lessgo's etymology back to the Samoan rapper Dei Hamo in his 2004 hit, "We gon ride." Of criticality, according to Lopesi, is the way in which Aotearoa-New Zealand-born and raised Samoan have integrated lessgo with a fa'aumu, colloquially known as chee-hoo! The integration of language and languaging, whereby Indigenous Pacific vernacular have been used to morph into local and colloquial slang within the context of Aotearoa-New Zealand, is a testament of the evolving nature of Pacific/Pasifika cultural identities in tu'atonga, something our communities need to constantly navigate, negotiate, and grapple with.

In a similar manner, we too draw from "lessgo" and its hype to actively trigger, invoke, and inspire our resistance work in academia, and to challenge the normalised practices that constrain and define criticality and critical thinking by, from, and through Moana-PacificPasifika perspectives. The spirit and energy of mālie, māfana, and vā have real creative potential when evoked and ignited within the loto, to do lōloto undertakings. ${ }^{38}$

Thaman reminds Pacific researchers that, although decolonising the mind is challenging because we read and write using the English language in university settings, we can at least try "to read and write more critically." ${ }^{39}$ Using lea fakaTonga and ngaahi 'ilo moe poto 'a e Tonga (Tongan knowledge and wisdoms) is key to this criticality work. This kind of intellectualising pushes boundaries and summons sensibilities that holistically draw from our embodied experiences as worthwhile learning. Although certain disciplines within the academy have defined and somewhat confined their knowledge traditions and practices, challenging the normalised resonances that imbue colonial (and neocolonial) tendencies and feelings are necessary. Our sense of deviation and deviance is inspired by a generative desire to empower and shift the ways our to'utangata grow, thrive, and flourish in our contexts. We see this as our becoming creatively critical.

\section{Creatively Critical Writing as Interrogatory Resistance: Working the "Hyphen"}

The hyphen $(-)^{40}$ is used as a writing tool that enables the creatively critical resistance depth work in this paper. As part of their postcolonial cross-cultural collaborative inquiry, Alison Jones and Kuni Jenkins capitalised on the hyphen as a tool to interrogate the coloniser-indigene construct as well as Pākehā-Māori relationships. ${ }^{41}$ They highlight the symbolic significance of the "working hyphen" in providing a criticality that enables scholars and researchers to dig deep into the interrelated connections and intersectional spaces that imbue tensions of power, struggle, entanglement, and resistance. Māori scholar and education philosopher Georgina Stewart utilises the hyphen to highlight the intercultural space as one that requires close analysis and interpretation. ${ }^{42}$ 
"Meaning making" as opposed to "meaning-making" (using the working hyphen) assumes a peaceful coexistence between the two terms. Our use of meaning-making prioritises Derrida's point that deconstructing oppositions brings to the fore an overturning of hierarchies and meanings. ${ }^{43}$ Prioritising "meaning" over "making" privileges knowing over doing and seeing. Positioning the working hyphen between meaning and making, as meaning-making, highlights deconstruction as an ongoing process that warrants further deconstruction and analysis, something we outlined earlier on in our paper. Meaning-making in this paper is a disruption of hierarchies and assumptions, emphasising the intersectional space as important to the making meaning of Indigenous or Tongan thought alongside Western thought.

The postcolonial scholar Homi Bhabha describes the third space as a liminal space, an inbetween space of "confusion and paradox, or liminality, within the context of (post)colonialism." ${ }^{44}$ Bhabha defines theory as liminality, "a response to and a real moment of intervention in peoples' daily lives as they try to grapple with the cosmic eddies of change around them. Because of such change, the notion of culture is not defined holistically but as enunciation." ${ }^{\prime 5}$ Fetaui Iosefo positions vā as symbolic of the third space, dynamic, where cultural change can be characterised by shifting identities. ${ }^{46}$ To aid critical depth work, working the hyphen provides interrogatory intersectional unpacking. We use the hyphen as a tool of defiance and resistance, seeking to unpack and deconstruct meanings. Not only that, as a writing tool, we use the hyphen to symbolise an ongoing space that shifts and is dynamic and fluid, though often ignored, "erased, softened, denied, consumed, expanded, homogenized, and romanticized." 47

\section{Creatively Critical Social Media Platforms: Tell me You're... Without Telling Me You're...}

Popular social media platforms like TikTok are communicative spaces that youth and adults use to express their sense of connection and belonging. The "tell me you're . . without telling me you're ..." is a popular trope people have embraced as a means and mode of expressive interpretation. Introspectively speaking, this critical autoethnographic reflection is a search for clarity through talanoa mālie, by shedding the layers of complex meaning that make up Pacific diversities beyond race and ethnicity. It is an unfolding of the Pacific intricacies that Te Punga Somerville calls us to engage with, to reveal their subtle yet complex specificities sensitive to the settler-colonial politics and conscientisation, therefore requiring careful unpacking. ${ }^{48}$ Through talanoa mālie, the revealing and unpacking of Pacific specificities moves diversity discourses in education beyond race and ethnicity and positions them as intersecting constructs with bicultural and inclusion.

\section{Pacific enough,}

am I?

I am

a koloa of my ancestors

of Tonga, Sāmoa, Niue

I am-son, brother, sister

I am-father, mother, husband, uncle, aunty

I am, not only me

but a part of "we"

a collectively greater

of wider affinity 
We are

our ancestors

the embodied koloa'ia

we are

not only us

but a part of "our"

a collectively greater

Moana-Pacific-Pasifika.

I am of us

enough.

Pacific enough, am I? (Sunday 24 October 2021, 2am)

"Pacific enough" challenges society's assumptions of what constitutes Pacific/Pasifika people in Aotearoa-New Zealand, assumptions that have evolved over time. Enough confronts our sense of Pacific/Pasifika identities, which are contextually and collectively made sense. Pacific/Pasifika people today in Aotearoa-New Zealand are not the same as they were in the 1950s and 1960s when they arrived on the whenua as part of the labour force. Our poem provides a point of entry, an attempt to connect or reconnect with the specificities and diversities amongst Pacific/Pasifika people by articulating the layers that shape our being and becoming within the Moananui-a-Kiwa landscape. "I am, not only me / but a part of "we"" is an acknowledgement and appreciation of what it means to develop our subjective sense of being and becoming Moana-Pacific-Pasifika: a collectively influenced process and a socialisation that relies on the social conditions and spaces within society. This critical autoethnographic account relies on our descriptive talatalanoa and deep introspection to unpack what it means to live as Pacific/Pasifika in tu'atonga.

\section{Creatively Critical Politics: Marginalised within the Marginalised}

Politics is an idea imbued with hegemonic tendencies and struggles of power. Political struggles between elites happen within marginalised groups, as well. The master's house, in Lorde's reference, is embedded in dominant Western paradigms that privilege whiteness and masculinity. It is important to note that in the context of Tongan society (and other Indigenous Pacific societies), the master's house also exists in the form of dominant paradigms and practices that favour the elite, that is, the socially and economically privileged. Seuta'afili Patrick Thomsen, a queer scholar of Samoan ancestry, confronts notions of privilege and elitism often permeated by social class, gender, race, sexuality, to name a few. Like many Rainbow Pacific community members, he has found the margins, "the in between," to be a safe space: resilience, resistance work, and drawing from their ancestral knowledges and practices aid in the rattling of the master's house. ${ }^{49}$

Marginalisation is a complicated notion when critical relations are confronted. Critical thinking is about confronting elitism and ideals within Moana-Pacific-Pasifika that perpetuate the marginalisation of the marginalised, such as the marginalisation of groups based on social class, gender, sexual orientation, religion and faith, or political beliefs. Racism may not be an obvious concern for our Moana-Pacific-Pasifika people often referred to as brown scholars, but the notion of colourism provides a layer of same race and racialised criticisms that confront and unfold the "intersections within and across different race relations and encounters." Alice Walker introduced colourism in 1983, she defined it as the prejudicial or preferential treatment of same race people based on their colour. ${ }^{51}$ The complicated relations linked to when the marginalised perpetuate marginalisation within their own group requires the practice of 
faithful relations through an approach like talanoa-vā, open to confronting the oppressive processes and systems (institutional and community based) that undermine Indigenous thriving and creatively critical becoming. ${ }^{52}$

Tongan society is hierarchical, and elitism festers within traditional and cultural practices. Even though traditional Tongan practices are worthwhile, there are cultural practices that favour the elite and marginalise the tu'a ${ }^{53}$ Critical theologian scholars of Tongan ancestry, Nasili Vaka'uta and Jione Havea both not only engage in defiant criticality that promotes social justice and active liberation but at the same time challenge status quo practices that undermine the tu'a within Tongan societal contexts. ${ }^{54}$ Working with Tongan and Western knowledges and concepts together enables a deep interrogation and unpacking of the diverse contexts and lived realities of communities who have now settled in tu'atonga and have also acquired and become acquainted with the cultural attitudes (shared understandings), mannerisms, and behaviours of their current residential contexts as Aotearoa-New Zealand-born and raised Tongans.

Although many Tongan researchers have drawn from lea fakaTonga and concepts as a counterpractice to Eurocentric approaches, the philosophical and practical tensions within research in higher education are not always openly articulated. ${ }^{55}$ To ignore such tensions can perpetuate practices that privilege certain groups over others. Tongan thought leaders 'Ana Maui Taufe 'ulungaki, Seu'ula Johansson Fua, and Mo'ale 'Otunuku's provocations within education research continue to fuel us and challenge the way we conceptualise, frame, and work with Tongan ideas and concepts. ${ }^{56}$ Johansson Fua affirms the need to tokanga mo fanongo, attributes of patience valued by to 'utangata Tonga. ${ }^{57}$

The accumulation of abstract or concrete knowledges valued by the university requires our subjective skills (referred to as soft skills) for meaning-making that matters and is appreciative of embodied states of learning. As identified by Thaman, wisdom is understood when Tongan people are able to make sense of the ngaahi 'ilo: what they know (knowledges accumulated) through fakapotopoto, the act-doing-implementing the ngaahi 'ilo in ways that benefit their communities. ${ }^{58}$ This is worthwhile learning and practice that ensures care and cultural continuity for Tongan and Moana-Pacific-Pasifika people.

\section{Creatively Critical Ongomālie and 'Uhingamālie: Critical Depth Work and Sense Making}

Raids in the dawn

echoing timeless trauma

beating heart, be still

why this whenua?

Partnerships, participation, protect

echoing mana within the moana

beating heart, be still

foki $\bar{a}$ ki he tupu'anga?

Be safe

... in the moana

knowing manaakitanga

... on the whenua 
Seeing diversity

... through ākonga and whanau

doing and caring for our becoming

... in the moana

beating heart, be still.

Beating heart, be still (Sunday 24 October 2021, 10am)

Critical depth work is a lōloto undertaking. 'Uhingamālie and ongomālie relate to things that feel and sound meaningful. Things that really matter to Tongan people. The dawn raids inflicted trauma to Pacific/Pasifika peoples in Aotearoa-New Zealand during the 1970s and highlighted issues linked to racism and the dehumanising of Pacific/Pasifika by the New Zealand government. These events also surfaced the collaborative past partnerships between Māori, the Ngā Tamatoa, and the Polynesian Panthers. Caring for the collaborative kaupapa between Māori and Moana-Pacific-Pasifika is creatively critical practice. Fuimaono Dylan Asafo provocatively critiques the New Zealand government's open and public apology and its capacity to result in genuine change for Pacific peoples ${ }^{59}$ His open critique of the government's apology is overlayed by their "superficial and inadequate gestures for reconciliation" and failure to acknowledge the "material and systemic impacts of the Dawn Raids era." 60 These impacts include the poverty inflicted on families as a consequence of the deportation of working family members, the laws and policies that continue to deny Pacific peoples' dignity and the inequitable pathways to permanent residency. Asafo's open critique visibilises the persistent systemic and societal structures that need shifting if any meaningful solution is to be realised by Pacific/Pasifika generations.

The concepts of ngaahi ongo (sounds, feelings) and ongo'i (to draw from one's senses and sensibilities) refer to visceral and felt knowledges. Ongo' $i$ is the understanding of experiences that matter, seen and felt as mālie and vā māfana. If caring for relationality and relationships is at the core of culturally responsive pedagogy within education - an approach valued by the Ministry of Education (MoE) through national education policy like the Tapasa - then our ngaahi ongo and ongo'i should be significant to teachers' professional growth and their creatively critical becoming in teaching and learning. ${ }^{61}$ How then, do university lecturers and educators enact and activate practices within their institutions that care for things that are mālie and generate vā māfana for Tongans?

Despite the understanding that Māori and Moana-Pacific-Pasifika people share ancestral connections in Te Moananui-a-Kiwa, there are very few opportunities to work together in relation to decolonial work in Aotearoa-New Zealand. ${ }^{62}$ The opportunities to work together differ across institutional places and spaces. In Kirikiriroa Hamilton, Pacific and Indigenous Studies as a disciplinary field is positioned within the Faculty of Māori and Indigenous Studies (FMIS). FMIS housing Pacific and Indigenous Studies can lead to opportunities for crosscollaboration between Māori and Moana-Pacific-Pasifika. However, not all will see this as an opportunity. Alice Te Punga Somerville reminds us to rethink and reimagine what this could look like in creatively critical ways, through teaching, research thinking, and writing. ${ }^{63}$

Te Tiriti o Waitangi positions Moana-Pacific-Pasifika as tauiwi or non-Māori. Bicultural relations for Māori and Moana-Pacific-Pasifika have not always been considered in relation to indigeneity within the moana; these have layers of complexity that require unpacking. Te Punga Somerville articulates the ancestral interconnections between tangata whenua and tangata o le moana. ${ }^{64}$ Matapo positions "Tagata o le moana" as the visceral manifestations of 
groups of people in Oceania who share similar yet diverse specificities in the Moana-collective assemblage of knowledges, cosmologies, and stories in which Māori are also ancestrally connected. ${ }^{65}$ Unpacking the complex layers within the notion of tauiwi from a Samoan perspective, Tamasailau Suaalii-Sauni fronted and brought into interrogation the concept of vā to connect with kaupapa Māori, a research theory and methodology centred on Mātauranga Māori and a desire for Māori sovereignty, self-determination, and reclamation. ${ }^{66}$ Doing so raises many questions: if Pacific/Pasifika are grouped as tangata tiriti within Aotearoa, then what does this look and feel like for Māori when they are outside of their whenua? ${ }^{67}$ What does it mean to be non-Māori when Māori are also ancestrally Moana peoples? What does it mean to enact partnership, participation, and protection in relation to mana whenua and mana moana? The questions we ask highlight the complexities that can fuel our creatively critical sense making as indigenous-indigene in Aotearoa-New Zealand and in the wider moana (Oceania).

\section{Creatively Critical Inclusion: Seeking to Activate}

Inclusively bicultural

biculturally inclusive

why does it matter?

Inclusion . . activate

You're an obsession that, evokes potential

You're a bicultural bi-product that, confronts cultural politics

wherein, who-in lies the power?

Yet the more we think about you,

the more distant you become

how do we activate and realise your potential?

We say you matter!

yet our classrooms categorically tear you down

I seek your leadership, courage, safety, and trust

Help us bounce back,

to strive for more, to reach beyond

to appreciate you for your worth!

Activating inclusion (Tuesday 17 August 2021, 5pm)

In the context of education in Aotearoa, one cannot think of inclusion without acknowledging biculturalism. ${ }^{68}$ In a 2008 paper written by the late great Māori academic and paramount chief of the Ngāti Whātua tribe, Sir Ian Hugh Kawharu, with the help of his daughter Merata Kawharu, alluded to a close friend Eric Schwimmer's definition of biculturalism:

Everybody learns one culture in his childhood and owes it primary allegiance. The bicultural person, in addition, accepts as legitimate the values of a second culture, is to some extent familiar with these values, and can turn to them if necessary, for subsidiary relationships. ... Any degree of familiarity with a second culture will soon 
lead to a contradictory situation where there are alternative correct ways of acting ... in such a situation, we have to make a choice; and we can be called bicultural only if we have made such a choice while aware of the value conflict involved in it. ${ }^{69}$

The notion of inclusion was borrowed by Schwimmer from Parsons as having three basic requirements: (1) equal civil rights; (2) a full share in the pursuit of the collective goals of society, in the processes of government and the exercising of power; and (3) the equality of resources and capacities necessary to make equal rights into fully equal opportunities. ${ }^{70}$

Biculturalism and inclusion are key drivers in the refresh of the Aotearoa-New Zealand curriculum. The push for inclusive practices in schooling should be within our bicultural relations and our becoming in Aotearoa-New Zealand as settlers from the Moana-PacificPasifika. Our interpretation, based on Schwimmer's definition of biculturalism, lies in his description of our doing in relation to moral judgement. Becoming bicultural, the choice and decision to do morally right despite conflicts with ones existing cultural values, is what matters most at that point in time. Creatively critical thinking is learning to appreciate and embrace various perspectives and worldviews.

Creatively critical practice, however, is learning to build trust within bicultural relations with Māori as tangata whenua and other settlers as tangata tiriti. Turangawaewae, symbolic of our sense of belonging as well as becoming, requires us to value the place-land-whenua on which we have come to stand and from which we have come to see (see tu'ufonua, tu' 'u'anga, tu'ungava' $\mathrm{e}^{71}$ ). Inclusion, from a bicultural lens, is linked to Kauwhata's claim that "mana is about right and authority. But no mana is sustainable without evidence of manaakitanga [generosity, care, respect], [a] consideration for the welfare and interests of others ... a growing sense of security in acting on the imperatives of right and duty, defining and redefining their place in the bicultural world around them. But what of power?"72 Activating inclusion using indigenous concepts centres on relationality and critical intersectionalities and connections through vahaloto, piri'anga, vā fealoaki, va, vā, veiyaloni (from Niue, Cook Islands, Tokelau, Sāmoa, Tonga, Fiji).

\section{Where to From Here? Ongoing Talatalanoa}

Creatively critical talatalanoa is an ongoing practice because it is not a way of knowing and understanding value recognised by Western-oriented academia. Reflexive thinking and practice through talatalanoa shape our critical becoming and unpacking of thinking and understanding across education and the social sciences; talatalanoa is an essential interdisciplinary practice for early career Pacific/Pasifika scholars. Such descriptive reflexivity and analyses are to be articulated across diverse academic disciplinary spaces in future. The questions we ask throughout our collaborative talatalanoa and engagement with each other and the literature emphasises the need for ongoing talatalanoa.

Creatively critical is learning to utilise strategically lea fakaTonga and Tongan concepts with Western concepts to unpack complex and nuanced meaning-making within academia. Indigenous Moana-Pacific-Pasifika concepts provide unique yet grounded worldviews, knowledges, and philosophies that appreciate our becoming in tu'atonga. Lōloto undertakings and critical depth work is an appreciation of meaning-making and sense making processes inherent in critical heart work: ngaahi me'a 'oku 'uhingamālie mo ongomālie kihe Tonga (things that genuinely matter to Tongan people). 
Creatively critical talatalanoa is learning to confront matters and situations that undermine the thriving and wellbeing of particular groups and voices often marginalised within the marginalised. It involves drawing from Indigenous practices and values guided by vā ethics to create open and generative conversational spaces where vulnerability is encouraged, and establishing trusting relations is fundamental to the practice of talanoa mālie and vā māfana. This requires deliberate collaboration and partnership between more experienced and early career researchers and scholars of Tongan ancestry, which is not always evident or accessible across Aotearoa-New Zealand universities.

Through talatalanoa and critical autoethnography, we have captured a dual practice that enables in depth criticality and ongoing meaning-making, guided and sustained by our vā ethical relations and connections, seeking to ensure that generosity, care, and respect flow throughout our critical engagement. Talatalanoa, talanoa mālie, vā, poetry, and the hyphen have provided such tools to defy and disrupt dominant Western frames of normalised practices within the education and the social sciences disciplines in academia.

\footnotetext{
${ }^{1}$ Ian Maclachlan, "Introduction: Deconstruction, Critical Thought, and Literature," in Jacques Derrida: Critical Thought, ed. Ian Maclachlan (New York: Routledge, 2004).

${ }^{2}$ Spirit or philosophy that enlivens and uplifts the hearts and minds of people, permeates and enriches their whole world.

${ }^{3}$ Inwardly heart-warming feelings.

${ }^{4}$ Linitā Manu'atu, "Mālie Conceptualizing: A New Philosophy of Tongan Education," in Encyclopedia of Educational Philosophy and Theory, ed. Michael A. Peters (Sage, e-book, 2016). ${ }^{5}$ Audre Lorde, The Master's Tools Will Never Dismantle the Master's House (London: Silver Press, Penguin Random House, 2017).

${ }^{6}$ Literal meaning of tu'atonga is "outside of Tonga." Figuratively, tu'atonga represents places and space i.e., the diaspora.

${ }^{7}$ Lorde, The Master's Tools Will Never Dismantle the Master's House.

${ }^{8}$ Lorde, The Master's Tools Will Never Dismantle the Master's House, 2-3.

${ }^{9}$ Jacoba Matapo and Jean M. Allen, "Traversing Pacific Identities in Aotearoa/New Zealand: Blood, Ink, Lives," in Poetry, Method and Education Research: Doing Critical, Decolonising and Political Inquiry, ed. Esther Fitzpatrick and Katie Fitzpatrick (Routledge, 2020), 207-20.

${ }^{10}$ Robert E. Rinehart, "Sensible Poets and the Poetic Sensibility," in Poetry, Method and Education

Research: Doing Critical, Decolonising and Political Inquiry, ed. Esther Fitzpatrick and Katie Fitzpatrick (NY: Routledge, 2020), 61.

${ }^{11}$ Rinehart, "Sensible Poets and the Poetic Sensibility," 63.

${ }^{12}$ We use hyphens here to highlight the iterative and ongoing nature of the "tala" in search of the "noa," something unknown.

${ }^{13}$ Timote Vaioleti, "Talanoa Research Methodology: A Developing Position on Pacific Research," Waikato Journal of Education 26 (2006): 21-34.

${ }^{14}$ Fetaui Iosefo, "Third Spaces: Sites of Resistance in Higher Education," Higher Education Research and Development 35, no. 1 (2016): 190.

${ }^{15}$ Stacey Holman Jones, "Living Bodies of Thought: The Critical in Critical Autoethnography," Qualitative Inquiry 22, no. 4 (2016): 228.

${ }^{16}$ Tui Atua Tupua Tamasese Ta“isi Efi, "Foreword," in The Relational Self: Decolonising Personhood in the Pacific, ed. Upolu Lumā Vaai and Unaisi Nabobo-Baba (Suva: The University of the South Pacific and The Pacific Theological College, 2017), xi.

${ }^{17}$ David Taufui Mikato Fa'avae, "Vā and Veitapui as Decolonial Potential: Ongoing Talatalanoa and Re-imagining Doctoral Being and Becoming," in Re-imagining Doctoral Writing, ed. C. Badenhorst, B. Amell and J. Burford (Boulder, CO: University Press of Colorado, 2021), 167-83.
} 
${ }^{18}$ Tui Atua Tupua Tamasese Ta 'isi 'Efi, "Clutter in Indigenous Knowledge, Research, and History: A Samoan Perspective," Social Policy Journal of New Zealand 25 (2005): 61-69.

${ }^{19}$ Talitiga Ian Fasavalu and Martyn Reynolds, "Relational Positionality and a Learning Disposition: Shifting the Conversation," The International Education Journal: Comparative Perspectives 18, no. 2 (2019): 11-25.

${ }^{20}$ Albert Wendt, "Towards a New Oceania," in Writers in East-West Encounters: New Cultural Bearings, ed. G. Amirthanayagam (Palgrave Macmillan, 1982), 202-15.

${ }^{21}$ Konai Helu Thaman, "Decolonizing Pacific Studies: Indigenous Perspectives, Knowledge, and Wisdom in Higher Education," The Contemporary Pacific 15, no. 1 (2003): 2.

${ }^{22}$ Tanya Wendt Samu, "The Pasifika Umbrella and Quality Teaching: Understanding and Responding to the Diverse Realities Within," Waikato Journal of Education 12 (2006): 35-49.

${ }^{23}$ Tanya Wendt Samu, "Social Studies: The Nebulous Cinderella Subject of the New Zealand School Curriculum" (masters' thesis, University of Auckland, 1998).

${ }^{24}$ Linitā Manu'atu, "Fonua, Tu'ufonua moe Nofofonua 'i Aotearoa New Zealand: Ko Ha Fakalanga Talanoa Pē," AlterNative: An International Journal of Indigenous Peoples 1, no. 1 (2005): 129-142.

${ }^{25}$ Manu'atu, "Fonua, Tu'ufonua moe Nofofonua 'i Aotearoa New Zealand."

${ }^{26}$ Manu'atu, "Fonua, Tu'ufonua moe Nofofonua 'i Aotearoa New Zealand"; Holman Jones, "Living bodies of Thought: The Critical in Critical Autoethnography."

${ }^{27}$ Linitā Manu'atu, "Tuli Hono Ngaahi Mālie: Pedagogical Possibilities for Tongan Students in New Zealand Secondary Schooling" (doctoral thesis, University of Auckland, 2000); Edmond Fehoko, "Social Space and Cultural Identity: The Faikava as a Supplementary Site for Maintaining Tongan Identity in New Zealand," New Zealand Sociology 30, no. 6 (2015): 131-39.

${ }^{28}$ Fehoko, "Social Space and Cultural Identity."

${ }^{29}$ Todd Henry and Apo Aporosa, "The Virtual Faikava: Maintaining Vā and Creating Online Spaces during COVID-19," Waikato Journal of Education 26 (2021): 179-94.

${ }^{30}$ Melenaite Taumoefolau, "Fola-he-ngalu (ep 01)," online talanoa, Youtube video, 4 February 2021, https://www.youtube.com/watch?v=76eBHUG_04w.

${ }^{31}$ Taumoefolau, "Fola-he-ngalu (ep 01)."

${ }^{32}$ Tēvita O. Ka'ili, "Lea Tonga: Kuo Hili, Lolotonga, Moe Kaha‘u," Fola-ne-ngalu Talanoa, https://fwc.to/index.php/webinars.

${ }^{33}$ Ka'ili, "Lea Tonga."

${ }^{34}$ Alice Te Punga Somerville, Once Were Pacific: Māori Connections to Oceania (Minneapolis: University of Minnesota Press, 2012).

${ }^{35}$ Marcia Leenen-Young et al., "Pillars of the Colonial Institution are like a Knowledge Prison: The Significance of Decolonizing Knowledge and Pedagogical Practice for Pacific Early Career Academics in Higher Education," Teaching in Higher Education (2021), DOI:10.1080/13562517.2021.1928062.

${ }^{36}$ Leenen-Young et al. "Pillars of the Colonial Institution are like a Knowledge Prison"; Patrick Thomsen, "Coming-out in the Intersections: Examining Relationality in how Korean Gay Men in Seattle Navigate Church, Culture and Family through a Pacific Lens," Journal of Homosexuality 68, no. 6 (2021): 1015-36; Lana Lopesi and Arcia Tecun (hosts), "Moana: Cosmopolitanism," audio podcast episode, in The Wai? Indigenous Words and Ideas, 18 July 2020; Fehoko, "Social Space and Cultural Identity"; Tim Baice et al., "Responding to the Call: Talanoa Va-vā, Early Career Network and Enabling Academic Pathways at a University in New Zealand," Higher Education Research and Development 40, no. 1 (2021): 75-89; 'Elisapesi Havea, Farita Tepora Wright, and Alvin Chand, "Going Back and Researching in the Pacific Community. Waikato Journal of Education 25, no. 1 (2020): 131-42; Ailie McDowall and Fabiane Ramos, "Doing Decoloniality in the Writing Borderlands of the PhD," The Australian Journal of Indigenous Education 47, no. 1 (2017): 54-63. ${ }^{37}$ Lana Lopesi, “An Etymology of Lessgo,” 25 September 2020, https://www.pantographpunch.com/posts/etymology-lessgo.

38 'Ana Koloto, "Tauhi Vā," in Encyclopedia of Educational Philosophy and Theory, ed. Michael A. Peters (Springer, e-book, 2016). 
${ }^{39}$ Thaman, "Decolonizing Pacific Studies."

${ }^{40}$ The en dash, as used here instead of the hyphen, also works to represent the hyphen space. The reference to "hyphen" draws on the work of other scholars who use that term to symbolize intersections, spaces in between, and margins. This is part of our resistance work.

${ }^{41}$ Alison Jones and Kuni Jenkins, "Rethinking Collaboration: Working the Indigene-Colonizer Hyphen," in Handbook of Critical and Indigenous Methodologies, ed. Norman. K. Denzin, Yvonna S. Lincoln, and Linda Tuhiwai Smith (Sage, 2008), 471-86.

${ }^{42}$ Georgina Stewart, "From Both Sides of the Indigenous-Settler Hyphen in Aotearoa New Zealand," Educational Philosophy and Theory 50, no. 8 (2018): 767-75, https://doi.org/10.1080/00131857.2016.1204904.

${ }^{43}$ Derrida, cited in Eugene B. Young, Gary Genosko, and Janell Watson, The Deleuze and Guattari Dictionary (London: Bloomsbury, 2013).

${ }^{44}$ Homi Bhabha, cited in Fetson Kalua, "Homi Bhabha's Third Space and African Identity," Journal of African Cultural Studies 21, no. 1 (2009): 25, https://doi.org/10.1080/13696810902986417.

${ }^{45}$ Bhabha, cited in Kalua, "Homi Bhabha's Third Space and African Identity."

${ }^{46}$ Iosefo, "Third Spaces."

${ }^{47}$ Jones and Jenkins, "Rethinking Collaboration," 4.

${ }^{48}$ Te Punga Somerville, Once Were Pacific.

${ }^{49}$ Patrick Thomsen, "Our Pacific Communities Do Have Love for Us," E-Tangata, 21 March 2021, https://e-tangata.co.nz/reflections/our-pacific-communities-do-have-love-for-us/.

${ }^{50}$ David Taufui Mikato Fa'avae, Arcia Tecun, and Sione Siu'ulua, "Talanoa Vā: Indigenous Masculinities and the Intersections of Indigeneity, Race, and Gender within Higher Education," Higher Education Research and Development (2021): 4, http://doi.org/10.1080/07294360.2021.1882402.

${ }^{51}$ Alice Walker, In Search of our Mother's Gardens: Womanist Prose (London: Harcourt Brace Jovanovich, 1983).

${ }^{52}$ Fa'avae et al., "Talanoa Vā."

${ }^{53}$ Nasili Vaka'uta, "Lau Faka-tu'a: Reading the Bible Tu'a-wise," in Oceania and Indigenous Theologies, ed. Elaine Wainwright, Diego Irarrazaval and Dennis Gira (London: SCM Press, 2010), 45-50.

${ }^{54}$ See: Vaka 'uta, "Lau Faka-tu 'a"; Jione Havea, "Postcolonize Now," in Postcolonial Voices from Downunder: Indigenous Matters, Confronting Readings, ed. Jione Havea (Eugene, OR: Pickwick Publications, 2017), 1-16.

${ }^{55}$ David Fa'avae, Alison Jones, and Linitā Manu'atu, "Talanoa'i 'a e Talanoa-Talking about Talanoa: Some Dilemmas of a Novice Researcher," AlterNative: An International Journal of Indigenous Peoples 12, no. 2 (2016): 138-50.

56 'Ana Maui Taufe 'ulungaki, "Look Back to Look Forward: A Reflective Pacific Journey," in $O f$ Waves, Winds, and Wonderful Things: A Decade of Rethinking Pacific Education, eds Mo'ale 'Otunuku, Unaisi Nabobo-Baba, and Seu'ula Johansson Fua (Suva, Fiji: USP Press, 2014), 1-15; Mo'ale 'Otunuku, "Tongan Parents' Conceptions of Schooling in New Zealand," in Of Waves, Winds, and Wonderful Things: A Decade of Rethinking Pacific Education, ed. Mo'ale 'Otunuku, Unaisi Nabobo-Baba, and Seu'ula Johansson Fua (Suva, Fiji: USP Press, 2014), 98-106; Seu'ula Johansson Fua, "The Oceanic Researcher and the Search for a Space in Comparative and International Education," The International Education Journal: Comparative Perspectives 15, no. 3 (2016): 30-41. ${ }^{57}$ Tokanga mo fanongo - being patient and paying close attention, listen, and observe.

${ }^{58}$ Konai Helu Thaman, "Looking Towards the Source: A Consideration of (Cultural) Context in Teacher Education," Access: Contemporary Issues in Education 11, no. 2 (1992): 88-93.

${ }^{59}$ Fuimaono Dylan Asafo, "Empty Gestures," E-Tangata, 15 August 2021, https://etangata.co.nz/comment-and-analysis/empty-gestures/.

${ }^{60}$ Asafo, "Empty Gestures."

${ }^{61}$ Ministry of Education (MoE), "Tapasā: Cultural Competencies Framework for Teachers of Pacific Learners," (New Zealand Government, 2018). 
${ }^{62}$ Hinekura Smith and 'Ema Wolfgramm-Foliaki, "We Don't Talk Enough: Voices from a Māori and Pasifika Lead Research Fellowship in Higher Education," Higher Education Research and

Development 40, no. 1 (2021): 35-48, http://www.doi.org/10.1080/07294360.2020.1856791.

${ }^{63}$ Te Punga Somerville, Once Were Pacific.

${ }^{64}$ Te Punga Somerville, Once Were Pacific.

${ }^{65}$ Jacoba Matapo, "Tagata o le Moana-The People of Moana: Traversing Pacific Indigenous Philosophy in Pasifika Education Research" (doctoral thesis, Auckland University of Technology, 2021).

${ }^{66}$ Tamasailau Suaalii-Sauni, "Va and Kaupapa Māori," in Critical Conversations in Kaupapa Māori, ed. Te Kawehau Hoskins and Alison Jones (Wellington: Huia, 2017), 161-78.

${ }^{67}$ Rita Dionisio and Angus Hikairo Macfarlane, "Tikanga Rua: Bicultural Spatial Governance in Aotearoa New Zealand,” New Zealand Geography Society 77, no. 2 (July 2021): 55-62, http://www.doi.org/10.1111/nzg.12303.

${ }^{68}$ Dionisio and Macfarlane, "Tikanga Rua."

${ }^{69}$ Ian Hugh Kawharu, "Biculturalism and Inclusion in New Zealand: The Case of Orakei," Anthropologica 50, no. 1 (2008): 49-56.

${ }^{70}$ Cited in Kawharu, "Biculturalism and Inclusion in New Zealand," 50.

${ }^{71} \mathrm{Tu}$ 'ufonua symbolises indigeneity; tu' $u$ 'anga refers to a place you stand on; tu'ungava'e is to do with a footstool, place to rest feet, but also a place to stand on and feel a sense of belonging.

${ }^{72}$ Kawharu, "Biculturalism and Inclusion in New Zealand," 54. 